\title{
THE ANALYSIS OF THE CASE LAW OF THE COURT OF JUSTICE OF EU ON THE UNFAIR COMMERICAL PRACTICES
}

\author{
[Analýza judikatury Soudního dvora EU o nepoctivých obchodních praktikách]
}

\author{
Radka MacGregor Pelikánová ${ }^{1}$ \\ ${ }^{1}$ Metropolitan University Prague, Dubečská 900/10, 10031 Prague 10 \\ Email: radkamacgregor@yahoo.com
}

\begin{abstract}
The EU ten years long strategy, Europe 2020, is coming up to its final assessment, including the interplay of both the competition and consumer protection in the internal single market. The pivotal legislative instrument in this respect, the Unfair Commercial Practices Directive ("UCPD"), was enacted even before Europe 2020 and was supposed to lead to a full harmonization of the protection against unfair business-to-consumer commercial practices, regardless whether misleading or aggressive, by the year 2007. The judiciary answer whether this has been achieved and supports the EU is to be learned from the competent court - Court of Justice of EU. A deep research is performed to provide data for a holistic Meta-Analysis which comparatively and critically assesses this strong, but not yet fully settled, case law consisting of almost 100 UCPD cases, and to expose it to the legislative wording, official EU statements and academic press. The key hypothesis suggests that the study of this case law in the light of the legislative wording, along with the official opinions of the EU and academic literature, provides valuable insights and suggestions about the status quo of achievements of the UCPD and Europe 2020 as well as the commitment of the EU and the attitude of the ultimate stakeholders, Europeans.
\end{abstract}

Keywords: CJ EU, Europe 2020, UCPD, unfair commercial practices.

JEL classification: K22, K41, L15, O38

Received: 5.10.2018; Reviewed: 2.11.2018; 12.11.2018; Accepted: 6.3.2019

\section{Introduction}

The EU ten years long strategy, Europe 2020, is rather steadily approaching its climax, along with the moment of the final assessment about whether a smart, sustainable and inclusive growth in the context of the single internal market was reached. The strategy includes five interrelated headline targets to be achieved by the year 2020, encompassing employment, innovation, education, poverty and social inclusion, and climate/energy (Staníčková 2018). In particular, the effective and efficient setting and operation of the digital single market is highly important, and its pre-requisites are fairness, trust and certainty, even in this virtual environment. Therefore, the interplay of both the competition and consumer protection in such a market, regardless whether in a tangible or an intangible form, is pivotal and logically becomes subject to a full harmonization. Indeed, already during the preceding decade long strategy, the European Commission moved to a rather ambitious legislative package which brought forth, among other items, the Directive 2005/29/EC concerning unfair business-toconsumer commercial practices in the internal market, i.e. Unfair Commercial Practices Directive ("UCPD"), which was supposed to lead to a full harmonization of the protection against unfair business-to-consumer commercial practices, regardless whether misleading or aggressive, by the year 2007. Therefore, we have the benefit of being able to observe the results of the more than ten years during which, across the whole of the EU, there should be applied the same regime and approaches regarding the protection of consumers from the effects of these unfair commercial practices. Is this an objective truth or merely a subjective illusion? The leitmotif of this contribution is that the ultimate judges in this respect are the judges from the Court of Justice of the EU, because they have a universal and ultimate 
competency to hear direct actions as well as indirect actions via requests for a preliminary ruling and because they truly employ it, as can be testified to by the total of almost 100 UCPD cases. A deep research is performed to provide data for a holistic Meta-Analysis which comparatively and critically assesses this strong, but not yet fully settled, case law, and to expose it to the legislative wording, official EU statements and the academic press. The key hypothesis suggests that the study of this case law in the light of the legislative wording, along with the official opinions of the EU, provides valuable hints and suggestions about the EU perspective and demands, not only regarding the UCPD but as well about the attitude of the ultimate stakeholders, European citizens, which make the selection whether to go to the CJ EU or not. The teleological interpretation, along with the inherently casuistic features of this case law, provides a unique dynamic interaction and assists in the partial confirmation of this hypothesis, points to problematic issues and even offers suggestions about current trends endorsed by the CJ EU vis-à-vis not only the UCPD. In addition, suggestions about the entire feasibility of the UCPD and recommendations for the improvement of the current system are presented. In sum, the case law of the CJ EU regarding the unfair commercial practices and the protection against them is a valuable and, sadly, so far deeply overlooked and underestimated source of information, with a critical impact on the $\mathrm{B} 2 \mathrm{C}$ setting in the $\mathrm{EU}$, especially if e-business is involved. The EU is right that the digital single market is fundamental and its failure could lead to the failure of the entire EU. The EU is right that, not only the macro and public aspects have to be addressed, but as well the micro and private aspects - such as those regulated by the UCPD. However, the EU is not fully right about how it proceeds in this respect and the CJ EU and its case law on the UCPD offers inputs for the very badly needed improvements, which can be very practical and ultimately not so difficult to be implemented. Boldly, the EU and Europeans cannot afford to pass on analyzing case law of the CJ EU on UCPD and this contribution aims to be one of the first steps on this long, difficult but indispensable journey. This is to be demonstrated based on the information provided by literature and legislative review (1.), methodologically processed (2.) and exposed to a rather robust UCPD case law (3.). The implied discussion and results (4.) lead to a rather surprising conclusion.

\section{Literature and legislative review}

The society of the $21^{\text {st }}$ century is marked by the globalization, eager competition and complex intergration (Piekarczyk 2016) and innovation attempts, which are challenging and not spontaneously smooth (Pohulak-Żołędowska 2016). Decades of digitalization further magnify these features (Vivant 2016) and blur the distinction between the tangible and intangible (MacGregor Pelikánová 2012). Neverthless, in this challenging setting, there are obvious certainties. One of them is the combination of the supranational and intergovernmental nature of the current EU, which has normative and other characteristics centered around the concept of the single market with significant institutional features and a competing interest group (Damro 2012). Another is the EU commitment to the single internal market with the famous quartet of freedoms (Cvik \& Pelikánová 2016), i.e. the unrestrained and fair competition is an obvious cornerstone of the modern European integration regardless of the EU confusion and vacillation between political desire, historical truth and economic reality (Chirita 2014).

The current ten year strategy for the EU, aka Europe 2020, has three priorities - smart, sustainable and inclusive growth (EC 2010), and aims to develop the technological and other potentials of the European economy (Balcerzak 2016a) in order to reach a higher and similar competitive level in the entire EU with a focus on social responsible stability (Pakšiová 2016). The goals of Europe 2020 lie in the perception of fact that a common market or internal market requires a certain degree of homogeneity in economic development of countries, 
which is not necessarily an automatic outcome of the European integration process but, eventually, has to be assisted by active policy interventions (both European or/and national interventions) what Europe 2020 represent (Melecký 2018). The EU 2020 R\&D target is hard to reach for some of CEE region countries (Bočková \& Meluzín 2016).

Although this drive for the globalization, digitalizaiton and competitivness is shared by the EU and all EU member states, nobody, including the EU, can ignore the notorious fact that these states, their businesses and individuals recognize and follow different social, political and economic traditions (MacGregorPelikánová 2017).

There are several roots and raisons for these differences, including the plain fact that, although continental law jurisdictions with their formalistic approach prevail (MacGregor Pelikánová 2014), still in the sphere of the EU rules on the existence of the unrestrained competition and its fairness (Turečková and Nevima 2017) and fair competition take perhaps even stronger inspiration from the common law jurisdictions. This trend is magnified by the nature and operation of the EU law, which penetrates into national laws of EU member states as an occupying authority on a foreign soil, by making use of a national procedural setting to directly incorporate and enforce its norms with the national jurisdictions of the EU member states (Azolai 2011). There are basically three sources of the EU law - primary, secondary and supplementary. The primary sources have an intergovernmental nature, create the constitutional foundation and include the Treaty on EU ("TEU"), Treaty on the functioning of EU ("TFEU") and Charter of fundamental rights of the EU ("Charter"). The secondary sources, such as Regulation and Directive, and supplementary sources, such as the case law of the CJ EU, have rather a supranational nature and must be in compliance with the primary sources. All sources of the EU law should be in line with the set strategy and implement it, i.e. they need to reflect Europe 2020 as a product of the European Commission influenced by both formal and informal institutions (Pasimeni \& Pasimeni 2016) and shaped as a policy for the economic dominance of the EU on the global market (Stec \& Grzebyk 2017). This overambitious attitude partially misses appropriate competencies (Erixon 2010) and might even lead to the increase of differences between EU member states (Çolak \& Ege 2013), both on a macro-economic level (Lajtkepova 2016 \& Balcerzak 2016b) and micro-economic level. Hence, some worship Europe 2020 while others consider Europe 2020 as a failure caused by the wrong setting and insufficient efforts of many European economies, especially the most important ones (Balcerzak 2015).

Based on the TEU and TFEU, the rules protecting the competition on the single internal market belong to the exclusive conferred competencies of the EU (Art.3(1)b TFEU - the establishing of the competition rules necessary for the functioning of the internal market). In contrast, the rules protecting the fairness of such a competition belong merely to the shared conferred competencies of the EU (Art.4(2)a TFEU - internal market, Art.4(2)f TFEU consumer protection). Therefore, the unfair commercial practices are covered by both the EU law and EU member states' laws and the key instruments of the EU law regarding unfair commercial practices are Directives. These Directives can go either for a simple harmonization or for a full harmonization which is close to the unification. They can take different approaches and perspectives, focusing on the market (Art.49 et foll. TFEU), consumer protection (Art.169 TFEU, Art.38 Charter), and freedom to conduct business (Art.16 Charter), etc. In addition, TFEU covers economic cohesion (Art.174 et foll.) and administrative cooperation (Art.197). The Charter incorporates the freedom to conduct a business (Art.16), right to property (Art.17), the consumer protection (Art.38) and right to good administration (Art.41) along with the right of access to documents (Art.42). 
Until 2005, EU member states have been dealing individually and particularly with unfair competition practices (Margoni 2016), including unfair commercial practices of businesses towards consumers, except for a few harmonization EU efforts to protect consumers. Then, the EU crossed the Rubicon and moved directly to the very strongly unifying harmonization, the full harmonization by the UCPD, despite strong conceptual disparities in EU member states' laws (Osuji 2011). Namely, the UCPD was adopted to contribute to the proper functioning of the internal single market and achieve a high level of consumer protection by approximating laws (Art.1 UCPD) and this should be done by a full harmonization (Art.4 UCPD). The UCPD generally banishes unfair business-to-consumer commercial practices (Art.3 and 5 UCPD), namely unfair commercial practices which are misleading and aggressive (Art.5 et foll. UCPD), and includes the blacklist of commercial practices that are always considered unfair (Annex I of the UCPD). Since the UCPD transposition deadline was set as 12th June, 2007 (Art.19 UCPD), we benefit by over ten years experience in interpreting and applying the harmonized regime of the UCPD in the entire EU (MacGregor Pelikánová 2017).

The UCPD is an ambitious strategic project of the EU dealing with unfair commercial practices under the auspices of the consumer protection law branch, while attempting to achieve objectives of consumer protection as well as competition protection in the sense of the protection of the European integration, based on the single internal market (MacGregor Pelikánová 2017). It might be suggested that after a long period of an excessive focus on competition (antimonopoly and antitrust) law, the EU appears to start to truly care about the daily operation of the single internal market while keeping consumers in mind (Tesauro \& Russo 2008). This is welcome by one academic stream, while others reject any attempts to mix IP, consumer protection, competition and unfair competition regimes (Chronopoulos 2014). This hesitation about the EU approach to the unfair commercial practices was not fully amended by official original explanatory notes or statements, i.e. by documents issued by the European Commission - COM (2013) 138 Communication on the application of UCPD and COM (2013) 139 Report. Recently, an improvement was achieved by the Guidance on the implementation/application of Directive 2005/29/EC on unfair commercial practices' of 25 May 2016 [SWD (2016) 163 final] and $\operatorname{COM(2016)~} 320$ Communication about a comprehensive approach to stimulating cross-border e-Commerce for Europe's citizens and busineeses. Well, the EU law goes here for the full harmonization and since iura novit curia, judges must interprete and apply the UCPD and judges from the CJ EU have to be the top experts and authorities in this respect. Their case law is a true supplementary source of law and has to be considered, if not followed, across the EU by all, including all national judges. So what does this case law tell us?

\section{Data and research methods}

The analysis of the case law of the CJ EU on the unfair commercial practices can be scientifically and academically performed by the holistic Meta-Analysis (Silverman 2013) while exploring primary and secondary data. The quantitative research and data are to be complemented by qualitative research, along with critical closing and commenting and refreshed by Socratic questioning (Areeda 1996). Namely, the pre-requirement for the fairness of such analysis is to consider information generated by the legislative framework and by academia and to explore a reasonably high number of relevant cases. Considered cases are from the CJ EU, because pursuant to the leitmotif of this contribution, the ultimate judge in this respect are the judges from the CJ EU. These judges have a universal and ultimate 
competency to hear direct actions as well as indirect actions via requests for a preliminary ruling and they truly employ it.

The search for the cases took advantage of the official case law database of the CJ EU, of the possibility to perform a key word search and the denomination of the key legislative instrument - UCDP with its full harmonization. Namely, based on the critical knowledge of the law setting and academic opinion streams, the CJ EU database with the search mask was accessed on the curia.eu domain, i.e. on the URL http://curia.europa.eu/juris/recherche.jsf?language=en and in the search mask the closed cases using the term „Uniform Commercial Practices Directive“ was requested. The search was performed in August 2018 and generated decisions issued between 2005 and 2018, i.e. the last decision was from $5^{\text {th }}$ July 2018. In order to double check and not miss cases using only abbreviations, a similar research was done by using the search term " $2005 / 29$ ". By contrast, indicating "UCPD" did not yield any results. Thereafter, a tedious examination was manually performed by the author, i.e. the author has not relied on any automatic mechanisms and in order to reach the highest possible fairness and accuracy of the analysis of these cases, she has checked each and every generated case and performed a teleological interpretation suitable for that type of case (MacGregor Pelikánová 2014). The author has a law background from both the continental as well as common law jurisdictions and so has the capacity to perform such an interpretation and to assess each and every case and categorize the yielded casuistic data in the overview table. In sum, all yielded cases and their key documents - judgments and opinions - were examined for the relevancy and, due to the extent of the results (over 100 documents), only the directly relevant which were issued after 2011 were considered and placed in Table 1.

The key hypothesis is that the study of this case law in the light of the legislative wording, along with the official opinions of the EU and academic literature, provides valuable hints and suggestions about the status quo of achievements of the UCPD and Europe 2020 as well as the commitment of the EU and the attitude of the ultimate stakeholders, Europeans. This overview table shows a unique dynamic interaction and is pivotal for the confirmation or rejection of the key hypothesis as well as for the related discussion and ultimate conclusions.

\section{The Case Law of the CJ EU on the Unfair Commercial Practices Directive.}

The search for CJ EU cases about the UCPD within the database curia.eu and while using the search term „Uniform Commercial Practices Directive“ generated eight pages of results with 157 documents reflecting nearly 100 closed cases. Double checking of these results were done by making a search using the search term " $2005 / 29$ " which generated five pages of results with 75 cases. All yielded cases and their key documents - judgments and opinions - were examined for their relevancy. Virtually all these documents were issued in the preliminary ruling proceedings and were either judgments ("PRJ") or opinions of the Advocate General (PRO), the only significant exception was C-421/12 condemning Belgium, see Table 1. In order to maintain relevancy, the focus was only on documents issued between 2012 and August 2018 and only on cases linked to the UCPD as such, i.e. the "approximation of laws" cases rather than on "transport", "taxation", "social policy" etc. Table 1, below, summarized the most relevant cases by providing their case number, name of one party, type of the document, concerned EU member state (nationality of the court raising the preliminary question to the CJ EU) and key content information, i.e. summary of the impact of the case on the interpretation and application of the UDRP or even a direct citation from the case mentioning UCPD. 
Table 1: Case law of the CJ EU on the UCPD since 2012 - Preliminary ruling/judgment (PRJ), Preliminary ruling/opinion of Advocate General (PRO) and Action for failure/judgment (AFJ)

\begin{tabular}{|c|c|c|c|}
\hline Case & Party & $\begin{array}{l}\text { Type / } \\
\text { country }\end{array}$ & \\
\hline C-339/17 & $\begin{array}{l}\text { Verein für lauteren } \\
\text { Wettbewerb eV }\end{array}$ & $\begin{array}{l}\mathrm{PRJ} / \\
\text { Germ. }\end{array}$ & $\begin{array}{l}\text { UCPD does not apply, i.e.businesses are free to choose between „all“, } \\
\text { „pure“, „100\%“, etc. for labelling textil products }\end{array}$ \\
\hline C-129/17 & $\begin{array}{l}\text { Mitsubishi Shoji } \\
\text { Kaisha }\end{array}$ & $\begin{array}{l}\mathrm{PRO} / \\
\text { Belg. }\end{array}$ & $\begin{array}{l}\text { Together with misleading and comparative advertising, EU law has } \\
\text { partially harmonised the law on unfair competition as regards business-to- } \\
\text { consumer commercial practices, see UCPD. }\end{array}$ \\
\hline C-632/16 & Dyson Ltd & $\begin{array}{l}\text { PRJ / } \\
\text { Belg. }\end{array}$ & $\begin{array}{l}\text { Interpretation of Art.7 UCPD - no misleading omission in labelling energy } \\
\text { class of vacuum cleaners }\end{array}$ \\
\hline C-568/16 & Faiz Rasool & $\begin{array}{l}\text { PRJ / } \\
\text { Germ. }\end{array}$ & Using UCPD to help definy „payment service“ for gaming arcade \\
\hline C-357/16 & UAB Gelvora & $\begin{array}{l}\text { PRJ/ } \\
\text { Lithu. }\end{array}$ & $\begin{array}{l}\text { Interpretation of Art. } 2 \& 3 \text { UCPD - UCPD covers relationship between a } \\
\text { debt collection agency and the debtor - consumer credit agreement }\end{array}$ \\
\hline C-356/16 & WAMO BVBA & $\begin{array}{l}\text { PRJ / } \\
\text { Belg. }\end{array}$ & $\begin{array}{l}\text { Interpretation of Art.3 UCPD - UCPD allows national law provisions } \\
\text { protecting in the case of plastic surgery advertisments }\end{array}$ \\
\hline C-295/16 & $\begin{array}{l}\text { Europamur } \\
\text { Alimentación SA }\end{array}$ & $\begin{array}{l}\text { PRJ / } \\
\text { Spain }\end{array}$ & $\begin{array}{l}\text { Interpretation of Art.1-7 UCPD - UCPD precludes a national provision, } \\
\text { which contains a general prohibition on offering for sale or selling goods at } \\
\text { a loss and which lays down grounds of derogation from that prohibition that } \\
\text { are based on criteria not appearing in that directive. }\end{array}$ \\
\hline C-175/16 & Hannele Hälvä & $\begin{array}{l}\text { PRO / } \\
\text { Finl. }\end{array}$ & Refers to C-304/08, EU about UCPD \\
\hline C-146/16 & DHL Paket GmbH & $\begin{array}{l}\text { PRJ / } \\
\text { Germ. }\end{array}$ & $\begin{array}{l}\text { Interpretation of Art.1-7 UCPD - an advertisement, , which falls within the } \\
\text { definition of an 'invitation to purchase', may satisfy the obligation } \\
\text { regarding information }\end{array}$ \\
\hline C-667/15 & Loterie Nationale & $\begin{array}{l}\text { PRJ / } \\
\text { Nether. }\end{array}$ & $\begin{array}{l}\text { Annex I to Directive } 2005 / 29 \text { concerning unfair business-to-consumer } \\
\text { commercial practices in the internal market must be interpreted as allowing } \\
\text { a commercial practice to be classified as a 'pyramid promotional scheme' }\end{array}$ \\
\hline & $\begin{array}{l}\text { Carrefour } \\
\text { Hypermarchés SAS }\end{array}$ & $\begin{array}{l}\mathrm{PRJ} / \\
\text { France }\end{array}$ & $\begin{array}{l}\text { Art.7 UCPD - advertising which compares the prices of products sold in } \\
\text { shops having different sizes or formats, where those shops are part of retail } \\
\text { chains each of which includes a range of shops having different sizes or } \\
\text { formats and where the advertiser compares the prices charged in shops } \\
\text { having larger sizes or formats in its retail chain with those displayed in } \\
\text { shops having smaller sizes or formats in the retail chains of competitors, is } \\
\text { liable to be unlawful, unless consumers are informed clearly and in the } \\
\text { advertisement itself that the comparison was made between the prices } \\
\text { charged in shops in the advertiser's retail chain having larger sizes or } \\
\text { formats and those indicated in the shops of competing retail chains having } \\
\text { smaller sizes or formats. }\end{array}$ \\
\hline & Luc Vanderborght & $\begin{array}{l}\text { PRJ / } \\
\text { Belg. }\end{array}$ & $\begin{array}{l}\text { Directive 2005/29/EC must be interpreted as not precluding a national } \\
\text { provision, which protects public health and the dignity of the profession of } \\
\text { dentists, first, by imposing a general and absolute prohibition of any } \\
\text { advertising relating to the provision of oral and dental care services and, } \\
\text { secondly, by establishing certain requirements of discretion with regard to } \\
\text { signs of dental practices. }\end{array}$ \\
\hline & $\begin{array}{l}\text { Canal Digital } \\
\text { Danmark A/S }\end{array}$ & $\begin{array}{l}\text { PRJ / } \\
\text { Denm. }\end{array}$ & $\begin{array}{l}\text { Interpretation of Art. } 6 \& \text { Art. } 7 \text { UCPD - must be interpreted as meaning that, } \\
\text { for the purposes of assessing whether a commercial practice must be } \\
\text { regarded as a misleading omission, consideration should be given to the } \\
\text { context }\end{array}$ \\
\hline C-544/13 & Abcur & $\begin{array}{l}\text { PRJ / } \\
\text { Swed. }\end{array}$ & $\begin{array}{l}\text { Even where medicinal products for human use, such as those at issue in the } \\
\text { main proceedings, fall within the scope of Directive } 2001 / 83 \text {, they can also } \\
\text { fall within the scope of Directive } 2005 / 29 / E C \text {, provided that the conditions } \\
\text { for application of that directive are satisfied. }\end{array}$ \\
\hline C-420/13 & $\begin{array}{l}\text { Netto Marken } \\
\text { Discount }\end{array}$ & $\begin{array}{l}\text { PRJ / } \\
\text { Germ. }\end{array}$ & $\begin{array}{l}\text { Services rendered by an economic operator which consist in bringing } \\
\text { together services so that the consumer can conveniently compare and } \\
\text { purchase them may come within the concept of 'services' referred to in } \\
\text { Article } 2 \text { of Directive 2008/95/EC of the European Parliament and of the } \\
\text { Council of } 22 \text { October } 2008 \text { to approximate the laws of the Member States } \\
\text { relating to trade marks. }\end{array}$ \\
\hline C-388/13 & UPC Magyarország & $\begin{array}{l}\text { PRJ / } \\
\text { Hungry }\end{array}$ & $\begin{array}{l}\text { Directive 2005/29/EC must be interpreted as meaning that the } \\
\text { communication, by a professional to a consumer, of erroneous information, } \\
\text { must be classified as a 'misleading commercial practice', within the } \\
\text { meaning of that directive, even though that information concerned only one }\end{array}$ \\
\hline
\end{tabular}




\begin{tabular}{|c|c|c|c|}
\hline & & & $\begin{array}{l}\text { single consumer. } 2 \text {. Directive } 2005 / 29 \text { must be interpreted as meaning } \\
\text { that, if a commercial practice meets all of the criteria specified in } \\
\text { Article } 6(1) \text { of that directive for classification as a misleading practice in } \\
\text { relation to the consumer, it is not necessary further to determine whether } \\
\text { such a practice is also contrary to the requirements of professional } \\
\text { diligence. }\end{array}$ \\
\hline C-515/12 & '4finance' UAB & $\begin{array}{l}\text { PRJ / } \\
\text { Lithun. }\end{array}$ & $\begin{array}{l}\text { Annex I, point } 14 \text {, of Directive } 2005 / 29 / \text { must be interpreted as meaning } \\
\text { that a pyramid promotional scheme constitutes an unfair commercial } \\
\text { practice only where such a scheme requires the consumer to give financial } \\
\text { consideration, regardless of its amount, for the opportunity to receive } \\
\text { compensation that is derived primarily from the introduction of other } \\
\text { consumers into the scheme rather than from the sale or consumption of } \\
\text { products }\end{array}$ \\
\hline C-421/12 & $\begin{array}{l}\text { European } \\
\text { Commission v. } \\
\text { Belgium }\end{array}$ & $\begin{array}{l}\text { AFJ / } \\
\text { Belg. }\end{array}$ & $\begin{array}{l}\text { By excluding members of a profession and dentists and physiotherapists } \\
\text { from the scope of the Law of } 14 \text { July } 1991 \text { on commercial practices, } \\
\text { consumer information and consumer protection, as amended by the Law of } \\
5 \text { June } 2007 \text {, transposing in national law Directive } 2005 / 29 / \text { EC ... the } \\
\text { Kingdom of Belgium has failed to fulfill its obligations under Articles } 2 \text { (b) } \\
\text { and (d), } 3 \text { and } 4 \text { of Directive } 2005 / 29 \text {; }\end{array}$ \\
\hline C-391/12 & $\begin{array}{l}\text { Stuttgarter } \\
\text { Wochenblatt GmbH }\end{array}$ & $\begin{array}{l}\text { PRJ / } \\
\text { Germ. }\end{array}$ & $\begin{array}{l}\text { Directive 2005/29/EC may not be relied on as against newspaper } \\
\text { publishers, with the result that, in those circumstances, that directive must } \\
\text { be interpreted as not precluding the application of a national provision } \\
\text { under which those publishers are required to identify specifically, in this } \\
\text { case through the use of the term 'advertisement' ('Anzeige'), any } \\
\text { publication in their periodicals for which they receive remuneration, unless } \\
\text { it is already evident from the arrangement and layout of the publication that } \\
\text { it is an advertisement }\end{array}$ \\
\hline C-281/12 & Trento Sviluppo & $\begin{array}{l}\text { PRJ / } \\
\text { Italy }\end{array}$ & $\begin{array}{l}\text { A commercial practice must be classified as 'misleading' for the purposes } \\
\text { of Article 6(1) of Directive 2005/29/EC of the European where that practice } \\
\text { contains false information, or is likely to deceive the average consumer, and } \\
\text { is likely to cause the consumer to take a transactional decision that he } \\
\text { would not have taken otherwise. Article } 2(\mathrm{k}) \text { of the directive must be } \\
\text { interpreted as meaning that any decision directly related to the decision } \\
\text { whether or not to purchase a product is covered by the concept of } \\
\text { 'transactional decision'. }\end{array}$ \\
\hline C-265/12 & Citroën Belux NV & $\begin{array}{l}\text { PRJ / } \\
\text { Belg. }\end{array}$ & $\begin{array}{l}\text { Article } 3(9) \text { of Directive } 2005 / 29 / \text { EC must be interpreted, as must } \\
\text { Article } 56 \text { TFEU, as not precluding a national provision, such as that at } \\
\text { issue in the main proceedings, which lays down a general prohibition - save } \\
\text { in the cases exhaustively listed by the national legislation - of combined } \\
\text { offers made to consumers where at least one of the components of those } \\
\text { offers is a financial service. }\end{array}$ \\
\hline C-59/12 & BKK Mobil Oil & $\begin{array}{l}\text { PRJ / } \\
\text { Germ. }\end{array}$ & $\begin{array}{l}\text { Directive 2005/29/EC must be interpreted to the effect that a public law } \\
\text { body charged with a task of public interest, such as the management of a } \\
\text { statutory health insurance fund, falls within the persons covered by the } \\
\text { directive }\end{array}$ \\
\hline C-657/11 & $\begin{array}{l}\text { Belgian Electronic } \\
\text { Sorting Technology } \\
\text { NV }\end{array}$ & $\begin{array}{l}\text { PRJ / } \\
\text { Belg. }\end{array}$ & $\begin{array}{l}\text { Article 2(1) of Council Directive } 84 / 450 / E E C \text { of } 10 \text { September } 1984 \\
\text { concerning misleading and comparative advertising, as amended by } \\
\text { Directive } 2005 / 29 / E C \text {... } \\
\text { must be interpreted as meaning that the term 'advertising', as defined by } \\
\text { those provisions, covers, in a situation such as that at issue in the main } \\
\text { proceedings, the use of a domain name and that of metatags in a website's } \\
\text { metadata. By contrast, the registration of a domain name, as such, is not } \\
\text { encompassed by that term. }\end{array}$ \\
\hline C-435/11 & $\begin{array}{l}\text { CHS Tour Services } \\
\text { GmbH }\end{array}$ & $\begin{array}{l}\text { PRJ / } \\
\text { Austria }\end{array}$ & $\begin{array}{l}\text { Directive 2005/29/EC must be interpreted as meaning that, if a commercial } \\
\text { practice satisfies all the criteria specified in Article 6(1) of that directive for } \\
\text { being categorised as a misleading practice in relation to the consumer, it is } \\
\text { not necessary to determine whether such a practice is also contrary to the } \\
\text { requirements of professional diligence as referred to in Article } 5(2)(\text { a) of } \\
\text { the directive in order for it legitimately to be regarded as unfair and, } \\
\text { therefore, prohibited in accordance with Article 5(1) of the directive }\end{array}$ \\
\hline
\end{tabular}

Source: Prepared by the author based on the data generated by the CJ EU case law databese [online][accessed on 22nd August 2018] Available at http://curia.europa.eu/juris/recherche.jsf?language=en

Therefore, the narrow, and more towards both relevancy and currency oreinted, search of the case law according to the above indicated criteria oriented on UCPD generated 24 documents 
in the closed cases. All cases, except one, were a preliminary ruling. The preliminary rulings were requested by national courts from a few EU member states and tackled similar issues.

To compare this CJ EU abundancy, a similar research was done with respect to the database of the Czech Supreme Court, i.e. once in the search, mask the term „2005/29“, and a list of 11 cases emerged. All these cases were decided by the two Senates - 23 Cdo and 32 Cdo (23 Cdo 2205/2012, 23 Cdo 2960/2012, 32 Cdo 3978/2011, 23 Cdo 4384, 32 Odo 229/2006, 23 Cdo 2500/2010, 23 Cdo 4044/2009, 32 Cdo 4661/2007, 32 Cdo 3895/2007, 23 Cdo 3868/2011, 23 Cdo 2415/2017). Further, this reserach was done with respect to the Czech Supreme Administrative Court and perhaps surprisingly generated a much longer list including over 200 cases mentionning ,2005/29“. The majority of these cases deals with the UCPD and its application rather within their obitur datum, but still a significant numbere of these cases have relevancy with respect to the UCPD. Nevertheless their analysis would go over the scope of this paper.

\section{Results and discussion}

In order to address the key hypothesis, a literature and legislative review was performed and on its base the case law of the CJ EU, with respect to the UCPD since 2012 was examined. Over one hundred closed cases were yielded by the automatic search and manually examined, i.e. read and assessed by the author. From this pool, 24 relevant ones were selected and placed in the overview Table 1. Although from a statistical point of view pools including 24 or even 100 elements are not impressive and at the very edge of the significance, in this context we can extract valuable hints and suggestions about the UCPD perception, interpretation and application.

Firstly, the UCPD is around since 2005 and after one decade of hesitations (MacGregor Pelikánová 2017), the European Commission made a set of new attempts to help to understand UCPD and make it more effective and efficient across the entire EU, see the Communication and Guidance from 2016 mentioned above. Along with this trend, the CJ EU once again showed its tandem co-operation with the European Commission and has worked hard to issue a solid case law. Namely, over one hundred cases have been already by the CJ EU while directly dealing with the UCPD and even once based on an action filed by the European Commission the CJ EU found that one EU member state, Belgium, failed to properly transpose the UCPD and hence committed a breach of the EU law. In this respect, it is plausible to conclude that the EU, especially the pro-European internal tandem, is serious about the UCPD and determined to work on its transposition and application in an efficient manner. This endeavor is neither futile nor waisteful because the UCPD appears as effective, i.e. as going in the right direction, namely to be a rather good instrument, despite the slight confusion over its goals and the perhaps too ambitious full harmonization (MacGregor Pelikánová 2017). Naturally, a further research in this respect would be desirable

Secondly, 23 of 24 selected cases were launched by national courts seeking the advice of the CJ EU about the interpretation and application of the CJ EU, i.e. these already decided cases are final preliminary rulings of the CJ EU on various aspects of the UCPD causing issues in national settings and leading to disputes brought to national judges. Germany and Belgium are EU member states where the transposition of the UCPD is a topic for individuals and businesses and even judges to which these individuals and businesses do not hesitate to bring their disputes. Judges from Germany presented, since 2012, at least six preliminary ruling requests about the UCPD, while judges from Belgium at least seven prelimnary ruling requests. Namely, of these 23 already finally by judgment addressed cases, six were brought 
by German courts and seven by Belgium courts. Therefore, Germany and Belgium took over a half of the relevant cases, i.e. 13 of 23. Courts from other EU member states were either less active (France, Denmark, Sweden, Finland, Lithunania) or basically not active at all (Southern Europe, Central Europe). Namely, from the PIGS states (infamous abbreviation for Portual, Italy, Greece and Spain due to their substantially instable economies shaking the entire EU) only Spain and Italy showed some interest, but e.g. Greece did not show any activity even in more remote spheers. Regarding Central Europe, one relevant case came from Austria and one remote one from Slovakia, with basically no interest at all shown by the Czech Republic and Poland, i.e. Czech and Polish individuals, businesses and judges. However, the conclusion that e.g. Czech judges do not decide any UCPD cases and do not seek advice from the CJ EU about the UCPD would be wrong. Indeed, as stated above, the Czech Supreme Court decided at least 11 cases about the UCPD and the Czech Supreme Administrative Court even many more cases. So the lack of preliminary ruling requests can be caused either by national ignorance of the UCPD or by the national confidence about the understanding of the UCPD. More research is definitely needed in this regard.

Thirdly, each of the relevant 23 cases had to deal with a certain provision of the UCPD. Interestingly, some provisions were, and are, much more "popular", i.e. needing CJ EU advice on the interpretation and application, than others. To these "popular" provisions, i.e. provisions about which national courts were not sure how to interpret and apply, belong Art.2 UCPD regarding various definitions, Art. 6 and 7 UCPD on misleading actions and misleading omissions and Annex I with the black list of commercial practices considered in all circumstances unfair. In contrast, no preliminary ruling requests were presented and thus no cases were decided by the CJ EU about the purpose of the UCPD (Art.1), the full harmonization (Art.4), about aggressive commercial actions (Art.8 et foll.), about codes of conduct (Art.10) and about the enforcement (Art.11). In sum, the UCPD prohibits B2C unfair commercial practices which can be typically misleading actions and omissions or aggressive practices. The case law focuses much more on the misleading commercial practices than aggressive commercial practices. Often these misleading actions and omissions deal with advertising and payment services. Often the CJ EU underlines the need of an ad hoc contextual assessment and this casuistic approach requires an extensive study of all circumstances. This is not suprising. However, it is surprising that the chronic problem of the definition of the key criterion - average consumer - is not addressed by the case law.

\section{Conclusion}

The UCPD is effective, because it is an important EU law instrument with a direct impact on national markets as well as the digital single market and generally in compliance with Europe 2020. The EU is right to bring rules in this field and perhaps even right to do it via the full harmonization. The UCPD is efficient, as its transposition, interpretation and application is, at least from 2016, proactively addressed by the European Commission and CJ EU. Yet the matter gets more complex once we move from the EU level to EU member states' level and the illustrious effectiveness and efficiency of the UCPD is fading. There is room and instruments for improvement, such as the study of the top and most current case law on the UCPD, namely the study of the relevant case law of the CJ EU on UCPD since 2012.

The key hypothesis is that the study of this case law in the light of the legislative wording, along with the official opinions of the EU and academic literature, provides valuable hints and suggestions about the status quo of achievements of the UCPD and Europe 2020 as well as the commitment of the EU and the attitude of the ultimate stakeholders, Europeans, is to be confirmed. These hints and suggestions entail at least three spheres. 
Firstly, over one hundred cases have been already decided by the CJ EU while directly dealing with the UCPD and 23 of the 24 most relevant cases are preliminary rulings of the CJ EU providing advice to national courts about the interpretation and application of the UCPD. This case law is solid and deserves respect and deeper study in order to enhance awareness in the entire EU and to make the full harmonization the reality. Boldly, here the EU seems to do a decent job and ball is on the side of EU member states.

Secondly, 1 of the 24 most relevant cases is not about preliminary rulings but instead about the failure to properly transpose the UCPD. It is surprising, in this case, that Belgium was found "guilty", while the majority of the remaining 23 cases on preliminary rulings were initiated by Belgian judges ( 7 cases out of 23) and German judges ( 6 cases out of 23). The legislature in Belgium made a mistake vis-à-vis the transposition of the UCPD, but Belgium judiciary can hardly be blamed as being too passive and over-confident with respect to UCPD. Very different suggestions can be proposed regarding the Southern and Central European states and even France (!). It would be worthy to explore if these states and their judges ignore the UCPD or rather feel no need to ask for advice from the CJ EU, and what would be the reasons for that is a good question! Hence, a national case law search and analyses should be brought.

Thirdly, the case law deals with definitions and misleading actions and omissions, but is silent about many other issues, such as aggressive commercial practices. This is surprising and even worrysome. The aggressive practices often have much worse consequences for consumers and thus Europeans should be very eager to fight agasint them and the European judges should seek a fully harmonized approach to assist in this respect. Another surprise that is raisisng concern is the fact that the case law does not deal with the chronic issue of the definition of the average consumer, i.e. does not bridge the differences in perception especially between EU law and German law.

The fair analysis of the case law of the CJ EU on the unfair commercial practices reveals a lot in these three spheres and even beyond, and even more can be found by expanding and deepening this study. There are many casuistic questions. Do Germans really care more about B2C fairness than the French? Are PIGS states as reckless regarding unfair competition as they were about their public finances? There are even more conceptual questions. Since the UCPD is a good EU instrument, why are some EU member states, their businesses, individuals and judges more committed to its perfect interpretation and application than others? Ultimately, can we have a digital single market with fair B2C practices in the EU?

\section{Acknowledgement}

This contribution was supported by GA ČR No. 17-11867S „Comparison of the interaction between the law against unfair competition and intellectual property law, and its consequences in the central European context."

\section{References}

[1] AREEDA, Ph. E., 1996. The Socratic Method. Harvard Law Review, 109(5): 911-922. ISSN 0017-811X.

[2] AZOLAI, L., 2011. The Force and Forms of European Legal Integration, EUI Working Papers, 2011/6. $\quad$ Retrieved July $1, \quad 2017$ from http://cadmus.eui.eu/bitstream/handle/1814/16894/LAW_2011_06.pdf?sequence=1 
[3] BALCERZAK, A. P., 2015. Europe 2020 Strategy and Structural Diversity Between Old and New Memember States. Application of Zero Unitarization Method for Dynamic Analysis in the Years 2004-2013. Economics \& Sociology, 8(2):190-210. ISSN 23063459 .

[4] BALCERZAK, A. P., 2016a. Technological Potential of European Economy. Proposition of Measurement with Application of Multiple Criteria Decision Analysis. Montenegrin Journal of Economics, 12(3): 7-17. ISSN 1800-5845. Doi: 10.14254/1800-5845.2016/12$3 / 1$.

[5] BALCZERZAK, A. P., 2016b. Fiscal Burden in the European Union Member States. Economic Annals - XXI, 161(9-10):4-6. ISSN 0013-3264.Doi: 10.21003/ea.V161-01.

[6] BOČKOVÁ, N. and T. MELUZÍN, 2016. Electronics Industry: R\&D Investments as Possible Factors of Firms Competitiveness. Procedia - Social and Behavioral Sciences, 220, 51-61. ISSN 1877-0428.

[7] CHIRITA, A. D., 2014. A legal-historical review of the EU competition rules. International and comparative law quarterly, 63 (2): 281-316. ISSN 0020-5893. Doi: 10.1017/S0020589314000037.

[8] CHRONOPOULOS, A., 2014. Legal and economic arguments for the protection of advertising value through trade mark law. Queen Mary Journal of Intellectual Property. 4(4): 256-276. ISSN 20459815. DOI: http://dx.doi.org/10.4337/qmjip.2014.04.01.

[9] CVIK, E. D. and R. MacGREGOR PELIKÁNOVÁ, 2016. Implementation of directive 2014/17/EU and its impact on EU and member states markets, from not only a Czech perspectives. Procedia Social and Behavioral Sciences, 220, 85-94. ISSN 1877-0428. Doi: 10.1016/j.sbspro.2016.05.472.

[10] ÇOLAK, M. S. and A. EGE, 2013. An Assessment of EU 2020 Strategy: Too Far to Reach? Social Indicators Research, 110(2): 659-680. ISSN 0303-8300. Doi: 10.1007/s11205-011-9950-2.

[11] DAMRO, C., 2012. Market power Europe. Journal of European Public Policy, 19(5): 682-699. ISSN 1350-1763.

[12] ERIXON, F., 2010. The Europe 2020 strategy: time for Europe to think again. European View, 9, 29. ISSN 1781-6858. Doi: 10.1007/s12290-010-0120-8.

[13] EUROPEAN COMMISSION, 2010. COM (2010) 2020 Communication from the Commission Europe 2020 - A strategy for smart, sustainable and inclusive growth. Retrieved August 8, 2018 from http://ec.europa.eu/eu2020/pdf/COMPLET\%20EN\%20BARROSO\%20\%20\%20007\%20 -\%20Europe\%202020\%20-\%20EN\%20version.pdf

[14] LAJTKEPOVA, E., 2016. Differences and Similarities in the Indebtedness of EU Member States after Last Financial Crisis. Oeconomia Copernicana, 7(4): 551-563. ISSN 2353-1827.

[15] MacGREGOR PELIKÁNOVÁ, R., 2012. And the best top level domain for European enterprises is... International And Comparative Law Review, 12(2):41-57. ISSN 12138770 .

[16] MacGREGOR PELIKÁNOVÁ, R., 2014. Selected current aspects and issues of European integration. Ostrava, CZ: Key Publishing. ISBN 978-80-7418-226-6. 
[17] MacGREGOR PELIKÁNOVÁ, R., 2017. European Myriad of Approaches to Parasitic Commercial Practices. Oeconomia Copernicana, 8(2): 167-180. ISSN 2353-1827. Doi: 10.24136/oc.v8i2.11.

[18] MARGONI, T., 2016. The Protection of Sports Event in the EU: Property, Intellectual Property, Unfair Competition and Special Forms of Protection. International Review of Intellectual Property and Competition Law, 47(4): 386-417. ISSN 0018-9855. DOI: 10.1007/s40319-016-0475-8

[19] MELECKÝ, L., 2018. The main achievements of the EU structural funds 2007-2013 in the EU member states: efficiency analysis of transport sector. Equilibrium. Quarterly Journal of Economics and Economic Policy, 13(2): 285-306. ISSN 1689$765 \mathrm{X}$.

[20] OSUJI, O. K., 2011. Business-to-consumer Harassment, Unfair Commercial Practices Directive and the UK- A Distorted Picture of Uniform Harmonisation? Journal of Consumer Policy, 34: 437. ISSN0168-7034. Doi: 10.1007/s10603-011-9175-4.

[21] PAKŠIOVÁ, R., 2016. CSR reporting in Slovakia. In: International conference on european integration 2016 : proceedings of the 3rd international conference on european integration 2016. Ostrava : VŠB - Technical University of Ostrava, pp. 698-707.

[22] PASIMENI, F. and P. PASIMENI, 2016. An Institutional Analysis of the Europe 2020 Strategy. Social Indicator Research, 127(3): 1021-1038. ISSN 0303-8300. Doi: 10.1007/s11205-015-1013-7.

[23] PIEKARCZYK, A., 2016. Contemporary organization and a perspective on integration and development. Oeconomia Copernicana, 7(3): 467-483. ISSN 2353-1827. Doi: 10.12775/OeC.2016.027.

[24] POHULAK-ŻOLEDOWSKA, E., 2016. Innovation in Contemporary Economies. Oeconomia Copernicana, 7(3), 451-466. ISSN 2353-1827. Doi: 10.12775/OeC.2016.026.

[25] SILVERMAN, D., 2013. Doing Qualitative Research - A Practical Handbook. $4^{\text {th }}$ Edition, London, UK: SAGE. ISBN 978-1446260159.

[26] STANÍČKOVÁ, M., 2017. Can the implementation of the Europe 2020 Strategy goals be efficient? The challenge for achieving social equality in the European Union. Equilibrium. Quarterly Journal of Economics and Economic Policy, 12(3): 383-398. ISSN 1689-765X.

[27] STEC, M. and M. GRZEBYK, 2017. The implementation of the Strategy Europe 2020 objectives in European Union countries: the concept analysis and statistical evaluation. Quality \& Quantity, 52(1): 119-133. ISSN 0033-5177. Doi: 10.1007/s11135-016-0454-7

[28] TEASURO, C. and C. RUSSO, 2008. Unfair commercial practices and misleading and comparative advertising: An analysis of the harmonization of EU legislation in view of the Italian implementation of the rules. Competition Policy International, 4(1): 193-222. Doi: $1554-0189$.

[29] TUREČKOVÁ, K. a J. NEVIMA, 2017. Evropské fondy - management rizik v oblasti veřejného školství. Scientific Papers of the University of Pardubice, Series D, 24(41): 206-216. ISSN 1211-555X.

[30] VIVANT, M., 2016. Building a common culture IP? International revue of intellectual property and competition law, 47(3). ISSN 0018-9855. Doi: 10.1007/s40319-016-0472-y 